\title{
Editorial
}

\section{Insider ownership and LBO performance}

Recent studies (like those of Holthausen and Larcker [1]) on the performance of reverse LBOs indicate that the private ownership by corporate insiders leads to superior corporate performance, even after the previously privatized companies went public again. Organizational, structural and behavioral characteristics of the private experience seem to persist (although reduced) for some years, even after reversing back to the public ownership.

It has always been theoretically appealing that privately concentrated ownership of active insiders would bring forth significant benefits compared to publicly dispersed ownership of absentee outsiders. Enriching the controlling/decision-making functions of employees by the strategic/risk-taking responsibilities of the owners seemed to be very high motivational boost.

However, the employee-owned businesses, although often successful, have not been entirely convincing in their performance. Who are the employees? Are they all those "employed" by the owners (i.e., workers, managers and directors), or just the narrower group of workers and operators?

Both absentee-owned and worker-owned businesses have to employ their management and directors, thus diluting significantly the ownership-motivational effect.

The optimal alternative is the ownership by insiders where the insiders form a coherent group. By coherent group we understand those owners who are capable of carrying out all functions of the enterprise: strategic, tactical and operational. Typically, such a group will consist of directors, managers, supervisory workers and skilled operators. Making any such subgroup dominant or exclusive would degrade the requisite coherence.

While absentee public owners do not have to form a coherent group (that can be hired), the insiders, in order to become effective as owners, have to retain their functional coherency by definition. Thus, worker-owned enterprises, although inside-owned, do not bring coherency to their ownership. They have to hire their management and directors, as if absentee owners. Such ownership affects only the operational levels, not all levels of corporate functions.

The best-performing organizational form will be, ceteris paribus, the private ownership by a coherent group of insiders.

There are privately, publicly and state owned companies: neither group of owners has to be a coherent group. There are outsider and insider owned companies: neither form has to be coherent. Typical outsider-owned (absentee-owned) public corporation would hire a coherent management/operation group, but its ownership functions still remain separate from it. Typical insider-owned private corporation is limited to workers/employees only, or to managers only. In fact, among the large variety of possible combinations, only the ownership by a coherent group of insiders, i.e., the optimal alternative, has not been broadly implemented.

The success of employee-owned businesses is derived more from their owners being corporate insiders rather than from their employees (workers and operators) becoming owners. It is the ownership by all important insiders (employees, officers, directors, etc.) which is at the core of superior performance.

Now even Russia, China and Poland have embraced public ownership by external corporate shareholders: under the banner of "privatization" they take their state-owned companies public. The dispersed, public and absentee form of corporate ownership has gone global. Everybody is doing it.

The distinct competitive advantage of such ownership forms has been lost. Yet, organizational, governance and ownership-based competitive advantage is still very significant and cannot be fully substituted by increasingly superior, even process-oriented operational efficiency.

The search for competitive advantage in the global economy will have to include the new forms of governance and ownership. The insider-owned enterprise, successfully tested in the US in the 1980s, offers such an alternative. 
Table 1

Main socioeconomic forms

\begin{tabular}{llll}
\hline & \multicolumn{3}{c}{ Control } \\
\cline { 2 - 4 } Ownership & State & Public corp. & Private corp. \\
\hline $\begin{array}{l}\text { State } \\
\text { ("everybody") }\end{array}$ & $\begin{array}{l}\text { Socialism } \\
\text { (anonymity) }\end{array}$ & $\begin{array}{l}\text { Perestroika } \\
\text { ("as-if" pseudo- } \\
\text { ownership) }\end{array}$ & $\begin{array}{l}\text { Yugoslavian experiment } \\
\text { (participation with no } \\
\text { responsibility) }\end{array}$ \\
$\begin{array}{lll}\text { Public } \\
\text { (shareholders) }\end{array}$ & $\begin{array}{l}\text { Fascism } \\
\text { (state holdings) }\end{array}$ & $\begin{array}{l}\text { Capitalism } \\
\text { (public) }\end{array}$ & $\begin{array}{l}\text { XXX } \\
\text { (not defined) }\end{array}$ \\
$\begin{array}{l}\text { Private } \\
\text { (insiders) }\end{array}$ & $\begin{array}{l}\text { Nazism } \\
\text { (state dictate) }\end{array}$ & $\begin{array}{l}\text { XXX } \\
\text { (not defined) }\end{array}$ & $\begin{array}{l}\text { Capitalism } \\
\text { (private) }\end{array}$ \\
\hline
\end{tabular}

Being an insider - an active employee, skilled worker, manager or director - endows the functions of ownership with the intensity and motivation which in terms of business performance could hardly be approximated by public or external absentee owners.

Clearly, corporate resources are often controlled and used by groups others than the owners (like hired management in a public corporation). The separation of functions of ownership and control through management hiring or resources leasing are quite common. One does not have to be owner to control the resources and one does not have to control the resources one owns.

This separation of functions is often dictated by individual skills and interests, not all owners know how to work, lead or manage, and not all employees can own. However, when active insiders also become owners, this separation of functions is overcome and the resources are controlled in the best possible, if not optimal, way.

The optimal socioeconomic system concentrates the ownership in the hands of specific private individuals (owners) and integrates in these persons both functions of resource ownership and control to the largest extent possible.

Consider, for example, the relation between of corporate ownership and operational resources control. Private corporations are characterized by concentrated equity ownership by insider groups (control and ownership integrated), while public corporations are typical for their publicly accessible equity dispersion among outsiders, the large masses of absentee owners (control and ownership separated).

Alternative socioeconomic forms can be identified and classified according to their degree of separation of ownership/responsibility and control/decision making functions. While traditional capitalistic forms continually search for optimum and thus oscillate between private to public and vice versa, the postcommunist state and collective forms were simply transformed into dispersed public forms, while mostly avoiding the true privatization: private ownership by insiders.

In Table 1 we summarize some of the better known combinations of corporate socioeconomic forms.

As seen in Table 1, it is possible to move from socialism towards systems of state ownership combined with public or employee control and decision making: that are the disastrous roads of inept perestroika or the ill-fated Yugoslavian "participation" experiments. It is also possible to move vertically: the way of public or private ownership combined with state control or dictate. The best way is along the diagonal, towards capitalism of fully private corporations of insiders.

\section{LBO-based privatization and performance}

Insider-owned businesses are better positioned to take advantage of modern organizational and management practices than absentee-owned ones. The integration of ownership, strategic, control and management functions within one concentrated and coherent group of insiders, typically through leveraged buyouts (LBO) assures the best, long-term oriented treatment of corporate resources.

The high-leverage, concentrated equity ownership by managers and employees, monitored by an LBO sponsor firm, creates an organizational structure that leads to value maximization. This expectation is now supported by experience and empirical research.

On the other hand, decline in leverage and the dispersion of equity ownership after an initial public offering would result in a decline in performance.

Even the reverse $L B O$ companies - companies that issue shares publicly after having gone private - retain some positive characteristics of the LBO organization and continue to outperform the average of the public companies. 
The key observation: as the equity owned by operating management and other insiders declined, so did operating performance.

These facts have been mostly ignored in large-scale "privatization" efforts in Eastern and Central Europe, especially in the massive "going public" projects, dispersing the equity to the citizenry, indiscriminately and through governmental vouchers or coupons.

So called "coupon privatizations" brought about the largest dispersion of equity ownership and the lowest possible engagement of corporate insiders. Thus "privatized" economies can be expected to minimize rather than to maximize their corporate performance.

These massive "going public" movements of Eastern and Central Europe in the 1990s are the very antithesis of the successful and very effective "going private" movement in the USA of the 1980s. While the US corporate performance is reaching the full benefits of its true privatization in the 1990s, the negative impacts of the hasty "going public" in Eastern and Central Europe are only now starting to be manifested.

Holthausen and Larcker [1] have observed that the change in the percentage ownership by operating management and non-management insiders is generally significant and positively associated with changes in operating performance. The greater the decline in the percentage of outstanding equity owned by these groups, the greater the decline in subsequent accounting performance.

In view of the above, setting the upper limits on the percentage of insider ownership allowed by law, like, for example, in the Czech Republic, looks like a sure ticket to corporate performance decline.

\section{The roots of performance of the insider-owned business}

The main thesis of this paper is that the superior performance of insider-owned business is rooted in its ability and motivation to implement the best global practices of management. Concentration of equity ownership in the hands of insiders is a crucial and necessary aspect, but in the final accounting, it is the deployment of the best practices which motivates the insider-owners much more than either the absenteeowners or the non-owning management.

There is no reason why the insider-owned business could not and should not be also the best-run business. Compared to public corporations, there are many additional incentives which induce these businesses to search for the best. For example, better employee empowerment, more widespread creativity and innovation, longer-term planning horizon, flatter organizational hierarchies, and so on, are increasingly important corporate competencies.

In the era of global competition, the best management and organizational practices are being disseminated and adopted globally at ever increasing rates. It can be postulated that a Global Management Paradigm (GMP) is emerging, surpassing the fiercely national management practices and the "special-conditions" managerial excuses which plague so many unrectructured and unreengineered corporate structures of Eastern and Central Europe.

In this sense, as always, the emerging GMP is again the domain of the US, Japanese and West-European corporations, while the rest is still lagging, relying on "cheap labor", refusing to learn and missing the opportunities offered by the global era.

\section{Reference}

[1] R. Holthausen and D. Larcker, Financial performance and organizational structure, Working paper, The Wharton School, University of Pennsylvania, 1997.

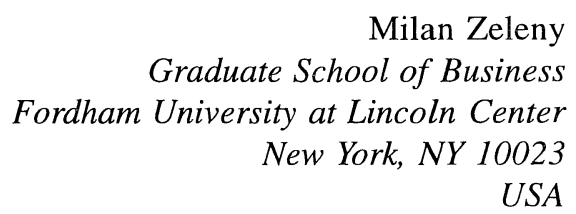

Milan Zeleny

Graduate School of Business New York, NY 10023

USA 